\title{
EFEK EKSTRAK DAN FRAKSI HERBAL Peperomia pellucida (L.) Kunth., TERHADAP BEBERAPA BAKTERI PATOGEN KULIT
}

\section{Extract and Fraction of Peperomia pellucida (L.) Kunth., Herbal's Against Several Dermal Pathogenic Bacteria}

\author{
Nurbaity Situmorang* \\ Politeknik Kesehatan YRSU Dr. Rusdi
}

*Corresponding author: E-mail: situmorang.n@gmail.com

\begin{abstract}
Abstrak
Penelitian ini bertujuan untuk mengetahui efek ekstrak dan fraksi hebal Peperomia pellucida (L.) Kunth., terhadap beberapa bakteri patogen kulit. Penelitian ini menggunakan tiga jenis bakteri patogen kulit yaitu : Staphylococcus aureus, Staphylococcus epidermidis dan Proteus vulgaris. Aktivitas ditentukan dari nilai MIC ("Minimal Inhibitory Concentration") dan MBC (Minimal Bactericidal Concentration) dengan metode dilusi memakai "Microtitreplate 96-well". Dari hasil penelitian didapatkan aktivitas terbaik dari ekstrak adalah terhadap Proteus vulgaris (MIC 7,81 ppm dan MBC 125 ppm). Aktivitas terbaik dari fraksi didapatkan pada fraksi n-heksana terhadap Proteus vulgaris (MIC 0,63 ppm dan MBC $250 \mathrm{ppm}$ ), untuk fraksi etil asetat (MIC 2,50 ppm dan MBC 500 ppm) sedangkan fraksi n-butanol dan fraksi sisa memiliki aktivitas yang sama (MIC 5 ppm dan MBC 500 ppm).oxysporum.
\end{abstract}

Kata kunci: Peperomia pellucida, Staphylococcus aureus, Staphylococcus epidermidis, Proteus vulgaris

\begin{abstract}
This reseach aims extract and fraction of Peperomia pellucida (L.) Kunth., herbal's against several dermal pathogenic bacteria. Three kinds of dermal pathogenic bacteria were used : Staphylococcus aureus, Staphylococcus epidermidis and Proteus vulgaris. Antimicrobial activity was determined base on their MIC (Minimal Inhibitory Concentration) and MBC (Minimal Bactericidal Concentration) through dilution method that used "Microtiterplate 96-well". The Result showed that the best activity of herbal extract was against Proteus vulgaris (MIC 7,81 ppm and MBC $125 \mathrm{ppm}$ ). The most active fraction was showed in $n$ hexane against Proteus vulgaris (MIC 0,63 ppm and MBC $250 \mathrm{ppm}$ ), the etil acetat fraction (MIC 2,50 ppm and $M B C 500 \mathrm{ppm}$ ), while the activity of $n$-butanol and aquaeous fraction (MIC 5 ppm and MBC 500 ppm, respectively).
\end{abstract}

Keywords: Peperomia pellucida, Staphylococcus aureus, Staphylococcus epidermidis, Proteus vulgaris

How to Cite: Situmorang, N, 2018, Efek Ekstrak dan Fraksi Herbal Perperomia pellucida (L.) Kunth. Terhadap Beberapa Bakteri Patogen Kulit, BioLink, Vol. 4 (2): Hal. 90-101 


\section{PENDAHULUAN}

Tumbuhan Peperomia pellucida merupakan alternatif tanaman obat yang memiliki kandungan kimia yang bersifat antimikroba terutama kelompok senyawa - senyawa alkaloid, tannin, saponin, polifenol, minyak atsiri dan senyawa lain yaitu kalsium oksalat dan lemak (Dalimartha, 2006). Lebih lanjut Hariana (2006) mengatakan bahwa, semua bagian tumbuhan ini bisa dimanfaatkan sebagai obat yaitu untuk mengobati abses, bisul, jerawat, radang kulit, luka bakar dan terpukul, penyakit ginjal, sakit kepala, penderita demam dan sakit perut. Di Brazil, P. pellucida lebih dikenal dengan sebutan Coracaozinho dan digunakan dalam pengobatan abses, furunkel dan konjungtivitis. Hasil tes farmakologi menunjukkan bahwa $P$. pellucida mempunyai kemampuan anti inflamasi (Arrigoni-Blank et al., 2004). Khan dan Omoloso (2003) juga telah menunjukkan bahwa ekstrak mentah ("crude extract") dan fraksi dari tumbuhan ini memiliki spectrum yang sangat luas dalam aktivitas antibakteri. Tumbuhan ini mempunyai kemampuan untuk menghambat aktivitas bakteri karena mengandung saponin dan polifenol. Kandungan senyawa lain seperti peperomin menyebabkan tumbuhan ini mempunyai aktivitas sitotoksik dan anti kanker (ArrigoniBlank et al., 2004 ; Xu et al., 2006).

Infeksi kulit menempati urutan ketiga dan berhubungan erat dengan keadaaan sosial ekonomi, penyebab yang umum adalah kuman Gram Positif yaitu Staphylococcus dan Streptococcus dan Gram negatif misalnya ; Pseudomonas aeruginosa, Proteus vulgaris, Escherichia coli dan Klebsiella (Djuanda, 2003). Menurut hasil survey yang didapatkan dari Balai Laboratorium Kesehatan Padang, penyakit kulit yang sering muncul akibat bakteri adalah penyakit kulit yang sering menghasilkan pus (nanah), infeksi luka bakar dan abses yang pada umumnya paling sering disebabkan oleh bakteri dari golongan Staphylococcus, $P$. vulgaris dan Pseudomonas aeruginosa.

Bakteri Staphylococcus aureus adalah salah satu dari sekian banyak penyebab infeksi purulen akut, sering ditemukan sebagai mikroba normal pada kulit, saluran pernafasan, saluran pencernaan dan vagina. $S$. aureus menginfeksi manusia dan hewan dengan tanda khas yaitu timbulnya peradangan, nekrosis dan pembentukan abses (Volk and Wheeler, 1988). Gejala klinis yang paling terkenal pada umumnya berupa bisul, bengkak yang nyeri di kulit dengan bagian tengah yang nekrotik dan jaringan ikat kulit yang reaktif (Ryan, 2003). S. epidermidis merupakan bakteri kokus Gram positif, sering ditemukan pada kulit dan di membran mukosa manusia dan hewan. Bakteri ini memerlukan jumlah yang cukup untuk menimbulkan infeksi atau disebut juga kurang virulen (tidak dapat menimbulkan penyakit tetapi dapat menimbulkan penggumpalan darah dalam rongga yang terbentuk akibat kerusakan jaringan).

Bakteri Proteus merupakan kuman Gram positif berbentuk batang lurus. Tidak mempunyai kapsul, sangat motil dengan flagel peritrik ditandai dengan gambaran menyebar (swarming) pada biakan agar. $P$. vulgaris dapat menimbulkan penggumpalan darah 
dalam rongga dan berkembang pada kulit yang rusak yang kemudian menimbulkan nanah (Ryan, 2003).

Pengobatan terhadap infeksi perlu memperhatikan pemilihan antibiotik yang memiliki sifat toksisitas selektif setinggi mungkin. Artinya antibiotik tersebut haruslah bersifat sangan toksik terhadap mikroba tetapi relatif tidak toksik untuk hospes (Setiabudy dan Gan, 1995). Selain itu, waktu pemberian dan konsentrasi yang diberikan perlu mendapat perhatian agar tidak menimbulkan kuman yang resisten (Volk and Wheeler, 1988). Akibat dari resistensi serta efek samping yang ditimbulkan dalam penggunaan antibiotik maka banyak dilakukan penelitian tentang bahan obat - obatan lain yang mempunyai efek terapeutik optimal dan efek samping yang serendah mungkin. Salah satu upaya ialah dengan menggunakan bahan obat tradisional dimana penggunaannya harus bisa dipercaya dan dapat dipertanggung jawabkan secara ilmiah (Depkes, 1981). Berdasarkan uraian di atas maka dilakukan penelitian mengenai : Aktivitas Ekstrak dan Fraksi Herbal P. pellucida (L.) Kunth., Terhadap Beberapa Bakteri Patogen Kulit.

\section{METODE PENELITIAN}

Penelitian ini dilakukan secara eksperimen dengan menggunakan metode Dilusi yaitu pengenceran bertingkat dengan memakai alat "Microtiterplate 96-well" secara in vitro. Dimana MIC dan MBC dari ekstrak dan fraksi ( $n$-heksana, etil acetat dan $n$ butanol) dari herbal $P$. pellucida terhadap beberapa kuman pada kulit $(S$. aureus, S. epidermidis dan P. vulgaris) dapat diketahui secara akurat, dengan 3 kali ulangan.

\section{Ekstraksi dan Fraksinasi}

Ekstraksi

Ekstraksi dilakukan dengan cara maserasi dengan pelarut methanol $(\mathrm{MeOH})$, daun $P$. pellucida yang telah dirajang halus dimasukkan kedalam botol gelap (wadah maserasi) kemudian dimaserasi dengan pelarut methanol. Maserasi dilakukan selama 5 hari dan sesekali diaduk, selanjutnya maserat disaring dan filtratnya diuapkan in vacuo sampai kental sehingga didapatkan ekstrak kental methanol.

Fraksinasi

Fraksinasi dilakukan dengan menambahkan aquadest pada ekstrak kental methanol tadi sehingga volumenya menjadi 1 liter. Selanjutnya difraksinasi dalam corong pisah dengan menambahkan pelarut dengan tingkat kepolaran berbeda mulai dari yang non polar ( $n$-heksana), semi polar (etil asetat) dan pelarut polar ( $n$-butanol).

Pertama dilakukan fraksinasi dengan $n$-heksana, sehingga diperoleh dua fraksi yaitu fraksi $n$-heksana dan fraksi air. Fraksi $n$-heksana diuapkan in vacuo didapatkan fraksi kental $n$-heksan. Fraksi air selanjutnya di fraksinasi dengan etil asetat sehingga diperoleh dua fraksi yaitu fraksi etil asetat dan fraksi air. Fraksi etil asetat diuapkan in vacuo sehingga didapatkan fraksi kental etil asetat. Begitu seterusnya dengan fraksi $n$-butanol dan fraksi air. Campuran tersebut sesekali diaduk secara searah sambil dikeluarkan udara dan gas - gas yang terperangkap 
didalamnya. Kemudian setelah kental dan kering, filtrat dari masing - masing fraksi diuji antibakterinya.

Pengujian aktivitas ekstrak dan fraksi herbal $P$. pellucida (L.) Kunth., terhadap beberapa bakteri patogen kulit

Aktivitas antimikroba dan penentuan Konsentrasi Hambat Minimum (KHM) diuji dengan metoda dilusi dengan menggunakan plat titer mikro dengan 96 lubang "Microtiterplate-96 well" yang telah disterilkan. Seluruh lubang pada plat tersebut, kecuali pada lubang ke-1 diisi dengan $180 \mu \mathrm{l}$ suspense kultur mikroba dan lubang ke-11 dan ke-12 diisi dengan $90 \mu \mathrm{l}$ suspensi kultur mikroba. Sedangkan lubang ke-2 sampai lubang ke-10 dengan $100 \mu$ suspensi mikroba. Untuk satu jenis mikroba dibuat tripel. Sampel uji sebanyak $20 \mu \mathrm{l}$ dimasukkan kedalam lubang pertama, yang telah berisi $180 \mu \mathrm{l}$ suspensi kultur bakteri dan dihomogenkan dengan cara mengaduk suspense dalam "Microtiterplate-96 well" tersebut dengan pipet mikro. Selanjutnya, pipet $100 \mu \mathrm{l}$ suspensi pada lubang pertama, pindahkan kelubang kedua yang telah berisi $100 \mu \mathrm{l}$ suspensi kultur bakteri lalu homogenkan. Dari lubang kedua dipipet sebanyak $100 \mu \mathrm{l}$ pindahkan ke lubang ke tiga, begitu seterusnya sampai lubang ke 10 dan 100 $\mu l$ larutan terakhir dibuang.

Untuk kontrol negatif pada lubang ke-11 ditambahkan $10 \mu$ l Metanol 10\% kedalam $90 \mu \mathrm{l}$ suspensi kultur bakteri tadi sehingga diperoleh konsentrasi $10 \%$. Sedangkan kontrol positif sebagai pembanding pada lubang ke-12 ditambahkan $10 \mu$ l larutan Tetrasiklin

16 ppm ke dalam $90 \mu \mathrm{l}$ suspensi kultur bakteri sehingga diperoleh 16 ppm $($ KHM Tetrasiklin $=16 \mathrm{ppm})$.

Daya hambat pertumbuhan mikroba ditunjukkan dengan perbedaan kekeruhan pada masing - masing lubang 'Microtiterplate-96 well" setelah masa inkubasi yang dapat diamati dengan mata (secara visual) dan dibandingkan terhadap kontrol positif dan kontrol negatif. Kekeruhan pada lubang yang diamati menunjukkan adanya pertumbuhan mikroba. Konsentrasi terendah dari sampel uji pada lubang yang terlihat bening menunjukkan tidak ada atau terhambatnya pertumbuhan mikroba merupakan angka Konsentrasi Hambat Minimum (KHM / MIC).

\section{Penentuan MIC ("Minimal Inhibiting Concentration")}

MIC ditandai dengan mengamati konsentrasi terendah dari sampel uji pada lubang yang terlihat bening menunjukkan sedikit sekali atau tidak adanya pertumbuhan mikroba setelah melakukan penanaman pada media dan penghitungan koloni bakteri setelah masa inkubasi 24 jam, merupakan angka MBC.

\section{Penentuan MBC ("Minimal Bactericidal Concentration")}

MBC ditandai dengan mengamati konsentrasi yang lebih tinggi dari MIC dari sampel uji pada lubang yang terlihat bening menunjukkan tidak adanya pertumbuhan mikroba sama sekali setelah melakukan penanaman pada media dan penghitungan koloni bakteri setelah masa inkubasi 2 x 24 jam, merupakan angka MBC.

\section{Analisa data}


Data dianalisis secara kuantitatif. Data yang dianalisis secara kuantitatif yaitu data KHM (MIC) dan data KBM (MBC) dari masing - masing fraksi dan ekstrak ketiga jenis bakteri tersebut.

\section{HASIL DAN PEMBAHASAN}

Tabel 1. Hasil Uji Aktivitas ekstrak kental herbal P. pellucida (L.) Kunth., terhadap $S$. aureus, $S$. epidermidis dan $P$. vulgaris

\begin{tabular}{|c|c|c|c|c|c|c|c|c|c|c|c|}
\hline \multirow[b]{2}{*}{ No } & \multirow[b]{2}{*}{ Bakteri } & \multicolumn{8}{|c|}{ Konsentrasi (ppm) } & \multirow{2}{*}{$\begin{array}{c}\text { MIC } \\
(\mathrm{ppm})\end{array}$} & \multirow{2}{*}{$\begin{array}{c}\text { MBC } \\
(\mathrm{ppm})\end{array}$} \\
\hline & & 1000 & 500 & 250 & 125 & $\begin{array}{l}62, \\
5\end{array}$ & 31,25 & 15,63 & $\begin{array}{l}7,8 \\
1 \\
\end{array}$ & & \\
\hline 1 & S. aureus & + & + & + & + & + & - & - & - & 62,50 & 250 \\
\hline 2 & S. epidermidis & + & - & - & - & - & - & - & - & 1000,00 & - \\
\hline 3 & P. vulgaris & + & + & + & + & + & + & + & + & $\leq 7,81$ & 125 \\
\hline
\end{tabular}

Ket: (+) : aktif

$(-)$ : tidak aktif

Kontrol $(+)$ menggunakan tetrasiklin sebagai pembanding $(\mathrm{MIC}=16 \mathrm{ppm})$

Dari tabel diatas, dapat dilihat bahwa ekstrak kental herbal P. pellucida (L.) Kunth., sangat aktif terhadap $P$. vulgaris dibandingkan $S$. aureus karena nilai MIC nya paling rendah, ini mengindikasikan bahwa konsentrasi 7,81 ppm sudah dapat menghambat pertumbuhan bakteri atau bersifat bakteriostatik terhadap $P$. vulgaris dan konsentrasi 62,50 ppm juga bersifat bakteriostatik terhadap $S$. aureus. Hal ini disebabkan oleh perbedaan kandungan dinding sel yang dimiliki bakteri berdasarkan pengelompokan Gram positif dan Gram negatif serta tebalnya peptidoglikan yang terdapat pada dinding sel bakteri Gram positif. $P$. vulgaris termasuk bakteri Gram negatif yang mempunyai tiga lapis dinding yang tipis sehingga mudah ditembus senyawa - senyawa antimikroba yang terdapat pada ekstrak kental herbal P. pellucida
(L.) Kunth., seperti flavonoid, alkaloid, tannin, minyak atsiri dan zat berkhasiat lainnya, sedangkan $S$. aureus termasuk kedalam bakteri Gram positif memiliki dinding yang tebal sehingga sulit ditembus oleh antimikroba yang terdapat pada ekstrak kental herbal $P$. pellucida (L.) Kunth. Menurut Prescott et al., (1990), bakteri Gram positif memiliki lapisan peptidoglikan yang tebal pada dinding sel sedangkan Gram negatif mempunyai lapisan peptidoglikan yang tipis dan lipopolisakarida pada membran luar. Bakteri gram positif berlapis tunggal namun mengandung lebih dari 50\% peptidoglikan dari berat kering sel bakteri tersebut, sedangkan bakteri Gram negatif hanya mengandung peptidoglikan sekitar $10 \%$ dari berat keringnya (Pelczar dan Chan, 1989). Ditambahkan oleh Nicklin et al., (1999), 
dinding sel bakteri terdiri dari peptidoglikan yang memberikan sel bakteri ketahanan, kekuatan dan perlindungan terhadap lisis.

Adapun perbedaan respon yang diberikan $S$. aureus dengan $S$. epidermidis adalah mungkin disebabkan karena perbedaan sifat bakteri itu sendiri. Hal ini sesuai dengan pernyataan Pelczar dan Chan (1989) jenis bakteri yang berbeda akan memiliki sifat yang berbeda sehingga respon yang diberikan terhadap antimikroba juga berbeda. Seperti diketahui bahwa $S$. aureus lebih peka terhadap senyawa yang bersifat mematikan pada kuman - kuman gram positif (Bonang dan Koeswardono, 1982). Ditambahkan Chattopaday et al., (2001) bahwa ekstrak kasar yang mengandung flavonoid, triterpen dan steroid menunjukkan aktivitas antimikroba terhadap beberapa strain yaitu S. aureus, Streptococcus faecalis dan Escherichia coli.

Dari data tersebut juga dapat dilihat bahwa ekstrak kental herbal $P$. pellucida (L.) Kunth., lebih aktif dalam menghambat pertumbuhan bakteri $P$. vulgaris dibandingkan tetrasiklin. Hal ini dapat disebabkan karena ekstrak kental herbal $P$. pellucida (L.) Kunth., mengandung berbagai senyawa metabolit sekunder diantaranya flavonoid, monoterpenoid, seskuiterpenoid, kuinon (Muhtadi, 2004), saponin, tanin, alkaloid dan minyak atsiri (Dalimartha, 2006). Cowan (1999) mengatakan bahwa senyawa - senyawa seperti fenol, saponin dan tanin yang terdapat pada tumbuhan merupakan antimikroba dan sebagai senyawa untuk pertahanan tubuh dari serangan penyakit. Target serangan ekstraseluler, mengendapkan protein dan mengganggu pembentukan dinding sel. Sedangkan aktifitas flavonoid sebagai antimikroba adalah karena kemampuannya merusak membran mikroba (Tsuchiya, 1996).

Nilai MBC (Minimum Bactericidal Concentration) yang didapat dari ekstrak kental herbal P. pellucida (L.) Kunth., terhadap masing - masing bakteri S. aureus dan P. vulgaris adalah 250 ppm dan 125 ppm. Konsentrasi tersebut mengindikasikan bakteriosid terhadap kedua jenis bakteri. Dari perbedaan nilai tersebut dapat dikatakan bahwa bakteri $P$. vulgaris lebih mudah dibunuh oleh ekstrak kental herbal P. pellucida (L.) Kunth., dibandingkan dengan $S$. aureus. Daya bunuh suatu ekstrak dipengaruhi juga oleh permeabilitas dinding sel bakteri. Daya bakterisid dari fenol yang bekerja dengan cara merusak membrane bakteri mengakibatkan cepat hilangnya kandungan sitoplasma bakteri sehingga menyebabkan lisis dan bakteri mengalami kematian (Nogrady, 1993). Turunan fenol juga berinteraksi dengan sel bakteri melalui absorbs sehingga terbentuk ikatan protein-fenol yang lemah yang selanjutnya diikuti oleh penetrasi fenol ke dalam sel yang menyebabkan presipitasi serta denaturasi protein (Siswandono dan Soekardjo, 1995). Hal ini diperkuat oleh pernyataan (Jawetz, 1996), bahwa salah satu prinsip kerja antimikroba adalah melalui penghambatan fungsi membran sel. Jika intergritas fungsional membran sitoplasma dirusak oleh suatu zat antimikroba, maka makromolekul dan ion lolos dari sel, akibatnya sel rusak dan terjadi kematian. 
Penelitian ini menggunakan tetrasiklin sebagai kontrol positif dengan nilai MIC sebesar $16 \mathrm{ppm}$ dan dari hasil percobaan juga didapatkan nilai MIC yang sama dengan nilai MBC nya. Hal ini membuktikan bahwa pada konsentrasi 16 ppm bakteri uji yang digunakan dapat dibunuh oleh antibiotik tersebut. Jika dibandingkan dengan nilai MBC masing - masing ekstrak, nilai MBC kontrol positif lebih baik. Hal ini dikarenakan tetrasiklin bekerja dengan menghambat biosintesis protein (pada saat translasi) yang terjadi di ribosom (Schunak, 1990). Katzung (1998) menambahkan bahwa tetrasiklin mempunyai kemampuan untuk menghilangkan ion - ion logam yang penting bagi kehidupan bakteri, seperti ion Mg.

Tabel 2. Nilai MIC dan MBC dari Fraksi Ekstrak Herbal P. pellucida (L.) Kunth., terhadap S. aureus, S. epidermidis dan P. vulgaris

\begin{tabular}{cllll}
\hline No & \multicolumn{1}{c}{ Fraksi } & Bakteri & \multicolumn{1}{c}{ Nilai MIC (ppm) } & Nilai MBC (ppm) \\
\hline \multirow{3}{*}{1} & n-hexana & & 7,81 & 500 \\
& etil acetat & \multirow{2}{*}{ S. aureus } & 31,25 & 500 \\
& $n$-butanol & & 125,00 & 1000 \\
& Sisa & & 125,00 & 1000 \\
& $n$-hexana & & 250,00 & $>1000$ \\
\multirow{2}{*}{2} & etil acetat & \multirow{2}{*}{ S. epidermidis } & 250,00 & $>1000$ \\
& $n$-butanol & & $>500,00$ & $>1000$ \\
& Sisa & & $>500,00$ & $>1000$ \\
& $n$-hexana & & $\leq 0,63$ & 250,00 \\
3 & etil acetat & P. vulgaris & 250,00 & 500 \\
& $n$-butanol & & 5,00 & 500 \\
& Sisa & 5,00 & 500 \\
\hline
\end{tabular}

Dari Tabel 2 dapat dilihat bahwa fraksi ; $n$-heksana, etil asetat, $n$-butanol dan sisa memiliki aktivitas yang berbeda terhadap bakteri $S$. aureus, $S$. epidermidis dan $P$. vulgaris, hal ini ditunjukkan oleh nilai MIC dan MBC yang bervariasi dari masing - masing fraksi terhadap ketiga jenis bakteri. Fraksi $n$-heksana memiliki aktivitas yang paling baik dari semua fraksi terhadap $S$. aureus yaitu dengan nilai MIC 7,81 ppm dan MBC 500 ppm, fraksi etil asetat mempunyai MIC 31,25 ppm dan MBC 500 ppm, sedangkan fraksi $n$-butanol dan sisa mempunyai nilai MIC yang sama yaitu 125 ppm dan MBC 1000 ppm, merupakan angka paling tinggi sekaligus memperlihatkan aktivitas paling rendah jika dibandingkan dengan dua fraksi lainnya terhadap $S$. aureus. Berbeda dengan aktivitas masing - masing fraksi terhadap S. epidermidis, fraksi n-heksana dan etil asetat mempunyai nilai MIC yang sama yaitu $250 \mathrm{ppm}$ dan MBC $>1000$ ppm, tingginya nilai MBC mengindikasikan bahwa kedua fraksi tersebut tidak aktif dalam membunuh $S$. epidermidis, sedangkan untuk fraksi nbutanol dan sisa dapat dikatakan bahwa kedua fraksi tersebut tidak memiliki nilai $\mathrm{MIC}>250 \mathrm{ppm}$ dan $\mathrm{MBC}>1000$ ppm. Selanjutnya, fraksi yang diujikan terhadap bakteri P. vulgaris memberikan pengaruh yang sangat baik 
terhadap bakteri tersebut, jika dibandingkan dengan kontrol positif tetrasiklin (MIC $16 \mathrm{ppm}$ ), aktivitas keempat fraksi masih lebih baik dalam menghambat pertumbuhan bakteri tersebut. Fraksi n-heksana mempunyai aktivitas yang paling baik dari semua fraksi terhadap P. vulgaris yaitu dengan nilai $\mathrm{MIC} \leq$ 0,63 ppm, jika dibandingkan dengan nilai MIC tetrasiklin (16 ppm) maka fraksi n-heksana memiliki aktivitas 25 kali jauh lebih baik dalam menghambat pertumbuhan $P$. vulgaris dan untuk nilai MBC yaitu 250 ppm. Fraksi etil asetat juga memberikan aktivitas yang baik terhadap $P$. vulgaris yaitu dengan nilai MIC 2,5 ppm (enam kali jauh lebih aktif dari pada tetrasiklin) dan nilai MBC 500 ppm, sedangkan fraksi n-butanol dan sisa memiliki aktivitas yang sama yaitu MIC 5 ppm dan MBC 500 ppm. Adanya kesamaan nilai MIC dan MBC yang ditunjukkan oleh fraksi n-butanol dan sisa terhadap masing - masing bakteri mengindikasikan bahwa kedua fraksi ini memiliki aktivitas yang sama terhadap masing- masing bakteri.

Dari semua perlakuan juga dapat diketahui bahwa keempat fraksi sangat aktif terhadap $P$. vulgaris, hal ini ditunjukkan dengan angari $P$. vulgaris MIC yang berkisar antara 0,63 - 5,00 ppm. Sensitivitas yang tinggi dari $P$. vulgaris ini dibandingkan dengan bakteri uji lainnya terhadap keempat fraksi kemungkinan disebabkan oleh perbedaan ketebalan lapisan peptidoglikan dari masing - masing bakteri uji. Dimana P. vulgaris termasuk kedalam golongan bakteri Gram negatif yang mempunyai lapisan peptidoglikan yang tipis dan tidak mempunyai kapsul sehingga memudahkan antimikroba masuk kedalam sel (Pelczar dan Chan, 1989).

Berdasarkan nilai MIC dari masing - masing fraksi, dapat dikatakan bahwa keempat fraksi tersebut lebih aktif dibandingkan tetrasiklin dalam menghambat pertumbuhan $P$. vulgaris. Hal ini berarti masing - masing fraksi mempunyai kemampuan menarik senyawa - senyawa aktif yang terdapat didalam herbal P. pellucida (L.) Kunth., sesuai tingkat kepolarannya secara optimal seperti ; minyak atsiri, alkaloid, tannin, flavonoid dan saponin. Masduki (1996) menyatakan bahwa minyak atsiri dapat menghambat pertumbuhan atau mematikan bakteri dengan mengganggu proses terbentuknya membran dan/atau dinding sel hingga membuat membran atau dinding sel tidak terbentuk atau terbentuk tidak sempurna sedangkan tanin mempunyai daya antibakteri dengan cara mempresipitasi protein, karena diduga tanin mempunyai efek yang sama dengan senyawa fenolik. Efek antibakteri tanin antara lain melalui reaksi dengan membran sel, inaktivasi enzim, dan destruksi atau inaktivasi fungsi materi genetik.

Alkaloid berperan dalam mengganggu terbentuknya komponen penyusun peptidoglikan pada sel bakteri, sehingga lapisan dinding sel tidak terbentuk secara utuh dan menyebabkan kematian sel tersebut (Robinson, 1998). Muhtadi (2004) menambahkan bahwa tanaman ini juga mengandung quinon. Aktivitas quinon diketahui dapat membentuk kompleks yang bersifat irreversible dengan asam amino nukleofilik dalam protein yang sering menghantarkan inaktivasi protein dan kehilangan fungsi sehingga 
menghambat proses terbentuknya membran/dinding sel.

Untuk nilai MBC, tetrasiklin (16 ppm) masih lebih baik dari pada nilai MBC dari keempat fraksi. Karena pada konsentrasi 16 ppm tetrasiklin dapat membunuh bakteri $S$. aureus, $S$. epidermidis dan $P$. vulgaris. Hal ini terbukti dalam percobaan setelah dilakukan pengamatan 2 x 24 jam yang diperlakukan terhadap bakteri uji memperlihatkan warna bening pada titerplate. Sementara fraksi n-heksana, etil asetat, n-butanol dan sisa baru dapat membunuh pada konsentrasi 250 1000 ppm. Menurut Turner (1991) cit. Alen (2005), suatu ekstrak tanaman bisa saja lebih aktif dalam membunuh dibandingkan fraksinya, karena keaktifan suatu senyawa ditentukan juga oleh kelarutan dari zat - zat yang aktif yang terkandung dalam senyawa tersebut serta sinergitas dari beberapa zat aktif yang terdapat pada ekstrak tanaman tersebut.

Dari keempat fraksi yang digunakan, dapat dinyatakan bahwa fraksi n-heksana merupakan fraksi yang paling aktif terhadap semua jenis bakteri yang diujikan kecuali terhadap $S$. epidermidis. Hal ini dapat dilihat dari nilai MIC nya yang paling rendah pada bakteri $P$. vulgaris $\leq 0,63$ ppm dan pada bakteri $S$. aureus 7,81 ppm. Dari data tersebut dapat dikatakan bahwa fraksi n-heksana mengandung senyawa aktif antibakteri patogen kulit terutama terhadap P. vulgaris dan S. aureus, yang mana seperti diketahui fraksi n-heksana mampu menarik senyawa - senyawa non polar yang mudah menguap seperti minyak atsiri yang bersifat antimikroba.
Fraksi n-heksana juga menunjukkan aktivitas antioksidan. Adanya aktivitas antioksidan menunjukkan bahwa adanya efek fenolik yang terdapat dalam tanaman ini. Sifat senyawa fenolik yang larut lemak menyebabkan aktivitasnya lebih besar terhadap $P$. vulgaris dibandingkan $S$. aureus. Hal ini disebabkan karena $P$. vulgaris merupakan bakteri Gram negatif yang mengandung banyak lipid dari pada Gram positif ( $S$. aureus). Dimana semakin banyak fenol yang terlarut dalam lemak akan menyebabkan aktivitas antimikrobanya semakin besar pula dengan menyebabkan kerusakan struktural atau pengubahan mekanisme permeabilitas mikrosom, lisosom, dan dinding sel.

Senyawa aktif lainnya dari tanaman ini adalah peperomin yang mempunyai aktivitas sitotoksik dan antikanker. Maka diduga senyawa ini juga bersifat sitotoksik terhadap $P$. vulgaris. Ditambahkan Khan dan Omoloso (2003) bahwa telah diisolasi beberapa senyawa flavonoid dari tanaman ini yaitu ; acacetin, apigenin, isovitexin dan pellucidatin. Menurut Basile et al., (1999) bahwa apigenin aktif dalam menghambat pertumbuhan beberapa bakteri Gram negatif salah satunya $P$. vulgaris dengan cara mengendapkan protein dan merusak pembentukan dinding sel sehingga selnya menjadi rusak dan mati. Dihubungkan dengan penelitian ini, diduga adanya senyawa antibakteri pathogen kulit yang terkandung dalam fraksi n-heksana, fraksi etil asetat dan fraksi n-butanol dari herbal P. pellucida (L.) Kunth., Namun fraksi n-heksana 
dapat dikatakan lebih aktif
dibandingkan ketiga fraksi lainnya
karena diduga lebih banyak menarik
senyawa aktif yang bersifat antibakteri
pathogen kulit. Hal ini terlihat dari nilai
MIC dan MBC yang lebih rendah
dibandingkan ketiga fraksi lainnya.
Dilihat dari rumus struktur senyawa
peperomin yang terkandung dalam $P$.
pellucida (L.) Kunth., senyawa ini
mengandung naphthalene, dimana
perubahan gugus fungsi methoxy dan -
OH akan mempengaruhi efek
aktifitasnya (Xu et al., 2006).
Sebagaimana diketahui naphthalene
juga mempunyai efek terapeutik sebagai
antiseptik yang biasanya digunakan
untuk bakteri penginfeksi usus dan
anthelminthic (Budavari, 1996), dengan
adanya senyawa ini juga menyebabkan
tanaman ini berpotensi untuk

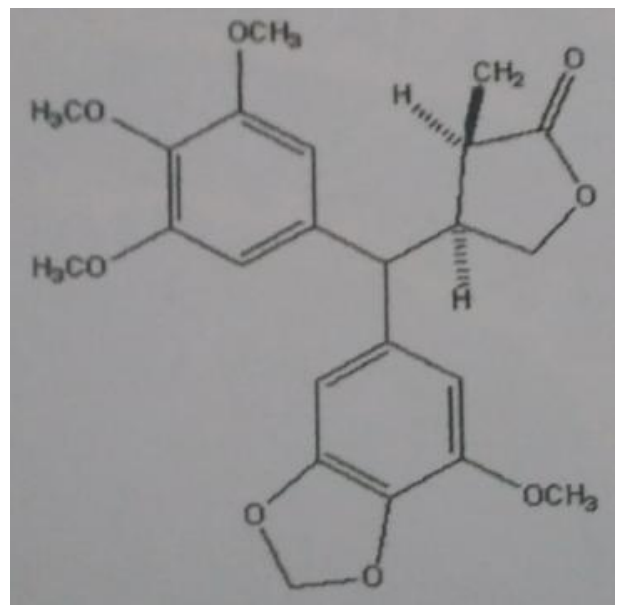

Gambar 1. Struktur Peperomin

Dari hasil tersebut diatas, dapat diketahui bahwa ekstrak kental dan fraksi herbal P. pellucida (L.) Kunth., sangat berpotensi untuk dikembangkan sebagai obat fitofarmaka anti bakteri patogen kulit khususnya yang disebabkan oleh S. aureus (misalnya ; jerawat, bisul, furunkel, karbunkel dan abses) dan P. vulgaris (misalnya ; bisul, kudis dan radang kulit).

\section{SIMPULAN}

Berdasarkan penelitian yang dilakukan tentang aktivitas ekstrak dan fraksi herbal P. pellucida (L.) Kunth., terhadap bakteri pathogen kulit maka dapat diambil kesimpulan sebagai berikut : Ekstrak dan fraksi herbal $P$. 
pellucida (L.) Kunth., dapat digunakan sebagai antibakteri patogen kulit yang disebabkan oleh $S$. aureus dan $P$. vulgaris. Sedangkan terhadap $S$. epidermidis dapat dikatakan tidak aktif.

Konsentrasi hambat minimum dari ekstrak kental herbal P. pellucida (L.) Kunth., masing - masing terhadap $S$. aureus dan $P$. vulgaris adalah 62,50 ppm dan 7,81 ppm, dengan nilai Konsentrasi Bunuh Minimum masing 0 masing nya adalah 250 ppm dan 125 ppm. Sedangkan Konsentrasi Hambat Minimum yang paling baik dari fraksi herbal P. pellucida (L.) Kunth., masing masing terhadap $S$. aureus dan $P$. vulgaris adalah 7,81 ppm dan 0,63 ppm dengan nilai Konsentrasi Bunuh Minimum masing - masing nya adalah 500 ppm dan 250 ppm.

\section{DAFTAR PUSTAKA}

Alen, Y., M. Oktavia., J. Jusfah dan D. Arbain. (2005). Potensi Ekstrak dan Fraksi Daun Tumbuhan Obat Malur (Brucea sumatrana Roxb.) Sebagai Calon Fitofarmaka Anti-diare. Abstract and Paper Proceeding Seminar Nasional dan Simposium Himpunan Kimia Bahan Alam Indonesia. Bogor

Arrigoni-Blank, M. R., E. G. Dimitrieva, E. M. Franzotti, A. R. Antoniolli, M. R. Andrade and M. Marchioro. (2004). Antiinflammatory and analgesic activity of Peperomia pellucida (L.) HBK (Piperaceae). J. Ethnopharmacol, 91, 215 218

Basile, A., G. S. Lopez-Saez., J. A. Cobianchi. (1999). Antibacterial Activity of Pure Flavonoids Isolated from Mosses. Phytochemistry. 52:1479-1482. In Bylka. 2004. Natural Flavonoids as Antimicrobial Agents. The Journal of the American Nutraceutical Association. Vol 7. No $2 ; 24-31$
Bonang dan Koeswardono. (1982). Mikrobiologi Kedokteran Untuk Laboratorium dan Klinik. Gramedia. Jakarta

Budavari, S. (1996). The Merck Index. Twelfth Edition. Merck Research Laboratories. New Jersey

Chattopadhyay, D., K. Maiti, A. P. Kundu., M. S. Chakraborty., R. Badra., S. C. Maudal and A. B. Manual. (2001). Antimicrobial Activity of Alstonia macrophylla. J. Ethnopharmacol 77 ; 49-55. In Contini. 2003. Antimicrobial Activity of Flavonoids and Steroids Isolated from Two Chromolaena species. Brazilian Journal of Pharmaceutical Sciences. Vol 39. No $4 ; 403-408$

Cowan, M. M. (1999). Plant Products as Antimicrobial Agents. Clinical Microbiology Reviews. Vol 12. No 4 ; 564582

Dalimartha, S. (2006). Atlas Tumbuhan Tumbuhan Obat Indonesia. Jilid 4. Puspa Swara. Jakarta.

Dasopang, E. S., dan Simutuah, A., (2016), Formulasi Sediaan Gel Antiseptik Tangan dan Uji Aktifitas Antibakteri dari Ekstrak Etanol Daun Pandan Wangi (Pandanus amaryllifolius), BioLink, Vol. 3 (1), Hal: 81-91

Djuanda, A., M. Hamzah dan S. Aisah. (2002). Ilmu Penyakit Kulit dan Kelamin. Edisi 2. Penerbit Fakultas Kedokteran Universitas Indonesia. Jakarta

Hariana, A. (2006). Seri Agrisehat Tumbuhan Obat dan Khasiatnya. Seri 3. Penebar Swadaya. Jakarta

Jawetz, E., J. L. Melnick dan E. A Adelberg. (1996). Mikrobiologi Kedokteran. Penerbit Buku EGC. Jakarta

Katzung, B. G. (1998). Farmakologi Dasar dan Klinik. Edisi III. Penerbit Buku EGC. Jakarta

Khan and Omoloso. (2003). Antibacterial Activity of Hygrophilla stricta and Peperomia pellucida. Fitoterapia : 2002 Jun ; 73 (3) : 251-254. Diakses dari http//search.medscapecom/ulsdient/ searchMedline.do?queryText=Plant\%2oE xtract. 06 Juni 2007

Masduki, I. (1996). Efek Antibakteri Ekstrak Biji Pinang (Areca catecu) Terhadap Staphyllococcus aureus dan Escherichia coli. Cermin Dunia Kedokteran. 109 : 2124

Muhtadi, A., Y. Susilawati dan L. Mulqie. (2004). Aktivitas Antidiabetes Ekstrak 
Etanol Herba Peperomia pellucida (L.) $H$. B. K. pada Tikus Putih yang Diinduksi Aloksan.http://farmasiunpad.net/konten. php?nama=Farmaka\&op=detailfarmaka\& $\mathrm{id}=45$. Diakses pada tanggal 20 Januari 2007

Nicklin, J. K. Graeme-Cook, T. Paget and R. Killington. (1999). Instant Notes in Microbiology. Bioscientific Publisher. Leeds

Nogrady, T. (1992). Kimia Medisinal Pendekatan Secara Biokimia. Terbitan Kedua. Penerbit ITB. Bandung

Pelczar dan Chan. (1989). Dasar - dasar Mikrobiologi. Penerbit Universitas Indonesia. Jakarta

Prescott, L. M., J. P. Harley and D. A. Klein. (1990). Microbiology. W. C. Brown Publisher 50-51. In Bylka. 2004. Natural Flavonoids as Antimicrobial Agents. The Journal of The American Nutraceutical Association. Vol 7. No. 2, 24-31

Robinson. (1998). Kandungan Organik Tumbuhan Tinggi. Penerbit ITB. Bandung

Ryan, K. J and R. C. George. (2003). Sherris Medical Microbiology an Introduction to Infectious Diseases. Edisi 4. United States of America. The Mc Graw-Hill Companies

Schunack, W. K. Mayer and H. Manfred. (1990). Senyawa Obat. Buku Pelajaran Kimia Farmasi. Edisi Kedua. Gadjah Mada University Press. Yogyakarta
Siswandono dan B. Soehardjo. (1995). Kimia Medisinal. Airlangga University Press. Surabaya

Setiabudy, R dan V. H. S. Gan. (1995). Farmakologi dan Terapi. Edisi 4. Bagian Farmakologi dan Terapi Fakultas Kedokteran Universitas Indonesia. Jakarta

Tsuchiya, H., M. Sato., T. Miyazaki., S. Fujiwara., S. Tanigaki., M. Ohyama., T. Tanaka and M. Linuma. (1996). Comparative Study on The Antibacterial Activity of Phytochemical Flavonones Against Methicillin-resistant Staphylococcus aureus. J. Ethnopharmacol. 50 : 27-34. In Cowan. 1999. Plant Products as Antimicrobial Agents. Clinical Microbiology Reviews. Vol 12 . No $4 ; 564-582$

Xu, S., M. M. Ning., C. H. Zhou., Q. R. yang and M. W. Wang. (2006). Bioactive Compounds from Peperomia pellucida. J. Nat. Prod. Vol 69. No 2 (247-350)

Volk, W. A dan M. F. Wheeler. (1988). Mikrobiologi Dasar. Jilid 3. Edisi 5. Erlangga. Jakarta

Wadani, S., A.,T., Yuliani, Rahayu, Y. S. (2015). Uji Ketahanan Lima Varietas Tanaman Cabai Merah (Capsicum annuum) terhadap Penyakit Tular Tanah (Fusarium oxysporum f.sp capsici). LenteraBio Vol.4 No.3 : 155-16o. 